\title{
The Economics of Class Action Waivers
}

\author{
Albert H. Choi \& Kathryn Spier ${ }^{\dagger}$
}

Many firms require consumers, employees, and suppliers to sign class action waivers as a condition of doing business with the firm, and the U.S. Supreme Court has endorsed companies' ability to block class actions through mandatory individual arbitration clauses. Are class action waivers serving the interests of society or are they facilitating socially harmful business practices? This paper synthesizes and extends the existing law and economics literature by analyzing the firms' incentive to impose class action waivers. While in many settings the firms' incentive to block class actions may be aligned with maximizing social welfare, in many other settings it is not. We examine conditions in which class action waivers can compromise product safety, facilitate anticompetitive conduct, and support harmful employment practices. Our analysis delivers a more nuanced, policybased critique of the recent U.S. Supreme Court cases, highlights several new unresolved issues, and identifies future challenges for legal scholarship to address.

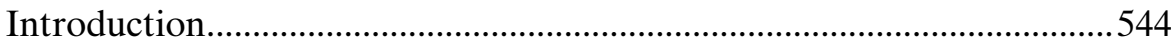

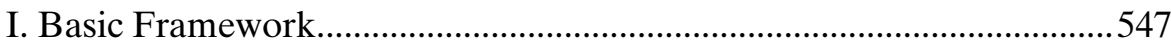

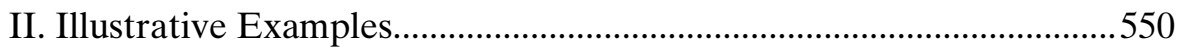

A. Private and Social Incentives Aligned.............................551

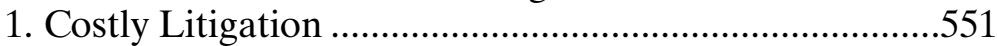

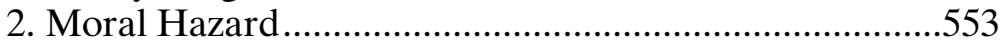

B. Private and Social Incentives Not Aligned........................555

1. Consumer Misperceptions..........................................556

2. Private Antitrust Litigation ..........................................558

3. Monopsonist Employer ............................................559

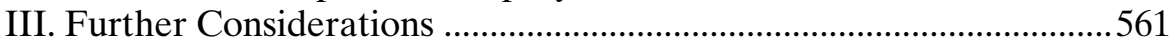

A. Consumer Risk Aversion ..................................................561

B. Agency Problems, Cy Pres Relief, and Frivolous

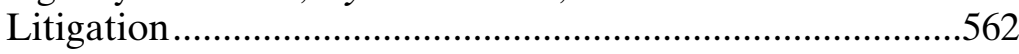

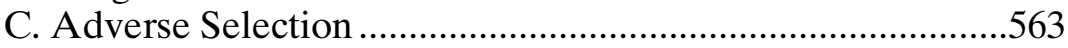

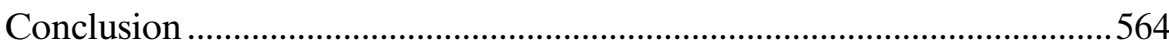

$\dagger$ Professor of Law, University of Michigan Law School, and Domenico De Sole Professor of Law, Harvard Law School. We thank Jennifer Arlen, Maureen Carroll, Brian Fitzpatrick, Richard Friedman, William Hubbard, Louis Kaplow, Daniel Klerman, Kyle Logue, Ed Morrison, David Rosenberg, Steven Shavell, and seminar audiences for many helpful comments and suggestions. We also thank Victor Roh for valuable assistance with editing. Comments are welcome to alchoi@umich.edu and kspier@law.harvard.edu. 


\section{Introduction}

The class action is a mechanism that allows plaintiffs who have been harmed by a common defendant to aggregate their claims and pursue a single collective action rather than many individual actions. ${ }^{1}$ In an attempt to avoid class actions, many firms require consumers, employees, and suppliers to sign class action waivers as a condition of doing business with the firm. ${ }^{2}$ Some waivers prevent consumers from pursuing class actions alleging false advertising, product defects and malpractice, and antitrust violations. ${ }^{3}$ Other waivers prevent employees from joining together and pursuing claims of discrimination or other workplace violations. ${ }^{4}$ In the securities law context, a class action waiver can prevent investors from jointly bringing lawsuits alleging fraudulent earnings statements or selfdealing by managers.

Notwithstanding the importance of class action waivers, previous law and economics literature has focused largely on the ex-post incentives of potential plaintiffs and their lawyers to pursue class actions and has ignored the incentives of potential defendants to block class actions ex ante with class action waivers. ${ }^{5}$ Are class action waivers serving the interests of

1. We use the phrases "class action" and "class action waiver" broadly to include multidistrict litigation (MDL) consolidations of individual lawsuits, class arbitration, and other methods for aggregating legal claims for the adjudication of common questions of law and fact. The differences among these mechanisms are not relevant for our analysis. See, e.g., FED. R. CIV. P. 18-20, 23 (outlining the federal rules for joinder and class actions).

2. The 2020 Carlton Fields Class Action Survey reports that $77.1 \%$ of companies use arbitration clauses in their contracts and $55.0 \%$ of these include class action waivers. 2020 Carlton Fields Class Action Survey, CARLTON FIELDS 5 (2020), https://classactionsurvey.com [https://perma.cc/2RBY-U8KL]. According to the Consumer Financial Protection Bureau's Arbitration Study, "Tens of millions of consumers use consumer financial products or services that are subject to pre-dispute arbitration clauses," and nearly all prohibit arbitration on a class basis. $A r$ bitration Study: Report to Congress, Pursuant to Dodd-Frank Wall Street Reform and Consumer Protection Act $\$$ 1028(a), CONSUMER FIN. PROTECTION BUREAU 9 (2015), https://files.consumerfinance.gov/f/201503_cfpb_arbitration-study-report-to-congress-2015.pdf

[https://perma.cc/GYX5-CQX8].

3. Arbitration can differ substantially from litigation in terms of costs, procedures, and damage awards (among others). For in-depth discussions of collective action waivers, see generally Myriam Gilles, Opting out of Liability: The Forthcoming, Near-Total Demise of the Modern Class Action, 104 MiCH. L. REV. 373 (2005); and Judith Resnik, Diffusing Disputes: The Public in the Private of Arbitration, the Private in Courts, and the Erasure of Rights, 124 YALE L.J. 2804 (2015).

4. Some estimate that $20 \%$ of employees are covered by mandatory arbitration clauses. See Alexander J.S. Colvin, Empirical Research on Employment Arbitration: Clarity Amidst the Sound and Fury, 11 EMP. RTS. \& EMP. POL'Y J. 405 (2007).

5. Many scholars argue that class actions allow plaintiffs to avoid duplication of expenses and achieve economies of scale. This is particularly valuable when the harms that the plaintiffs have suffered are very small relative to the costs of litigation, because in such cases individual actions would have negative expected value (NEV). See generally Robert G. Bone, Class Action, in 8 ENCYCLOPEDIA OF LAW AND ECONOMICS: PROCEDURAL LAW AND ECONOMICS 67 (Chris William Sanchirico ed., 2d ed. 2012); Kenneth W. Dam, Class Actions: Efficiency, Compensation, Deterrence, and Conflict of Interest, 4 J. LEGAL STUD. 47, 60 (1975); Geoffrey P. Miller, Class Actions, in 2 THE New PalgRAVE DictionARY OF ECONOMICS AND THE LAW 257 (Peter Newman ed., 1998). Class actions are also valuable when individual claims have positive expected value 
society by avoiding wasteful litigation and rent-seeking by lawyers? ${ }^{6}$ Or are they blocking meritorious legal claims and facilitating socially harmful business practices? These issues are of practical as well as academic interest. The importance of class action waivers has come to the fore through recent U.S. Supreme Court cases, such as Concepcion, ${ }^{7}$ Italian Colors, ${ }^{8}$ and Epic Systems, ${ }^{9}$ that have largely endorsed companies' ability to block class actions through mandatory individual arbitration clauses.

This paper builds on the existing law and economics literature ${ }^{10}$ by focusing on the defendant-firms' incentive to impose class action waivers on potential plaintiffs. We foremost identify conditions under which a firm's private incentive to block or allow class actions may or may not be aligned with maximizing social welfare. ${ }^{11} \mathrm{We}$ also suggest what the law can do when a firm's private incentive is not aligned with the interest of society. Our analysis delivers a more nuanced, policy-based understanding of the recent U.S. Supreme Court cases and identifies several new unresolved issues and future challenges for legal scholarship.

We present our arguments using a series of illustrative examples to demonstrate the effects of class action waivers. Class action waivers prevent plaintiffs from achieving economies of scale and other efficiencies in litigation, but also potentially limit the value captured by lawyers and third

(PEV) insofar as class actions reduce the per-plaintiff costs of litigation or allow the plaintiffs to optimize their investments. See David Rosenberg \& Kathryn E. Spier, Incentives to Invest in Litigation and the Superiority of the Class Action, 6 J. LEGAL ANALYsis 305, 347-48 (2014). For an earlier analysis on class action waivers, see generally Keith N. Hylton, The Economics of Class Actions and Class Action Waivers, 23 SuP. CT. ECON. REV. 305 (2015).

6. According to Beisner et al., "One of the most heavily criticized class-action abuses has been the use of class-action settlements to generate huge fees for lawyers and little or nothing for the allegedly injured consumers." John H. Beisner, Matthew Shors \& Jessica Davidson Miller, Class Action "Cops": Public Servants or Private Entrepreneurs?, 57 STAN. L. REV. 1441, 1445 (2005). But see Brian T. Fitzpatrick, Do Class Action Lawyers Make Too Little?, 158 U. PA. L. REV. 2043 (2010).

7. AT\&T Mobility LLC v. Concepcion, 563 U.S. 333 (2011). The case dealt with mandatory individual arbitration provisions in cell phone service contracts. The U.S. Supreme Court overturned the lower court's ruling that such provisions were "unconscionable" under California contract law.

8. Am. Express Co. v. Italian Colors Rest., 570 U.S. 228 (2013). The plaintiffs argued that American Express was exercising monopoly power over charge cards to force retailers to accept higher fees on American Express's credit cards. Although the plaintiffs argued that bringing individual antitrust arbitrations, in accordance with the credit card service agreements, would be prohibitively costly, the Court ruled that the plaintiffs still retained the right to pursue the antitrust remedy.

9. Epic Sys. Corp. v. Lewis, 138 S. Ct. 1612 (2018). In that case, the Court ruled that mandating individual arbitration on plaintiff-employees (pursuant to the employment agreement) did not violate the National Labor Relations Act, notwithstanding an earlier, contrary interpretation by the National Labor Relations Board.

10. See supra note 5 .

11. As is standard in the law and economics literature, our measure of social welfare is simply the aggregate value captured by the actors in the economy (firms, consumers, lawyers). We do not consider distributional consequences of legal rules or notions of fairness and morality. For a thoughtful discussion of the normative analysis of legal rules see STEVEN SHAVELL, FOUNDATIONS OF ECONOMIC ANALYSIS OF LAW 663-72 (2004). 
parties. Most (but not all) of our illustrative examples focus on settings where class action lawsuits are financially viable but individual lawsuits are not (because the cost of bringing an individual claim exceeds the potential damage award at trial). In these examples, the class action waiver operates as a de facto waiver of liability. ${ }^{12}$

We show that in well-functioning markets with sophisticated consumers, the firms' incentive to allow class actions or block them by requiring consumers to sign waivers at the time of purchase is aligned with social welfare. If the costs of litigation are significant and there are few offsetting benefits from litigation, litigation is likely a social waste. If firms already have adequate incentives to manufacture safe products and provide appropriate working conditions, perhaps through market and regulatory monitoring mechanisms, class action waivers would be privately and socially desirable. Allowing class actions would lead to wasteful litigation spending, thereby decreasing social welfare. When firms do not already have adequate incentives and imposing liability on the firms is necessary to induce the firms to make unobservable safety investments, so long as the consumers rationally expect the consequences of the liability system, firms will voluntarily choose the dispute resolution format that solves the deterrence problem at the lowest cost possible. In these cases, both the firm and the consumers get to share the increase in social surplus from choosing the optimal dispute resolution forum. ${ }^{13}$

When markets are not well-functioning, however, then firms' private incentive to block class actions by requiring consumers to sign class action waivers may be socially excessive. By blocking class actions and chilling litigation, firms can exploit market failures and divert value from consumers and employees to the detriment of society. When consumers misperceive the impact of signing a class action waiver, or are unaware that they are signing one,${ }^{14}$ the price that consumers are willing to pay for the product will not adjust to reflect the presence or absence of a class action waiver. In this case, firms will impose class action waivers as a cost savings device, and product safety and reliability may be compromised. Furthermore, in market settings where regulations are necessary to avoid corpo-

12. More generally, plaintiffs may have an excessive or insufficient incentive to sue. See generally Steven Shavell, The Fundamental Divergence Between the Private and the Social Motive to Use the Legal System, 26 J. LEGAL STUD. 575 (1997).

13. According to the Coase Theorem, in settings without transactions costs or other impediments, the assignment of property rights should not matter. Private parties would negotiate to an economically efficient outcome. See R.H. Coase, The Problem of Social Cost, 3 J.L. \& ECON. $1(1960)$.

14. For evidence that individuals do not read the fine print in contracts, see Yannis Bakos, Florencia Marotta-Wurgler \& David R. Trossen, Does Anyone Read the Fine Print? Consumer Attention to Standard-Form Contracts, 43 J. LEGAL STUD. 1 (2014). 
rate misconduct (such as antitrust and employment laws) but public enforcement mechanisms are weak, class actions may be socially desirable. ${ }^{15}$ Private lawsuits brought against firms that engage in illegal price fixing, or against employers that breach their duties towards workers, can be a critical complement to public enforcement efforts. ${ }^{16}$ Unlike the earlier set of cases, the reason the firm's incentives are not aligned is that the firm does not capture any increase in surplus from choosing the socially optimal dispute resolution system.

The Essay is organized as follows. Part I introduces our basic framework and presents a simple benchmark example to anchor the analysis. Part II presents a series of variations of the benchmark example to demonstrate how firms' incentive to impose class action waivers may or may not be aligned with maximizing social welfare. Part III provides an informal discussion of other important wrinkles and complications, including potential agency problems and possible frivolous lawsuits engendered by class actions. The Conclusion provides some thoughts for future research.

\section{Basic Framework}

This Essay presents simple, numerical examples to examine a firm's incentive to allow class actions or block them by requiring consumers to sign class action waivers. Our primary focus is on settings where individual lawsuits have negative expected value (NEV) but class actions have positive expected value (PEV). ${ }^{17}$ For example, a consumer who entered into a contract with AT\&T Mobility for cellular telephone service would probably not find it worthwhile to pursue an individual claim if the likely gross recovery is on the order of $\$ 30 .{ }^{18}$ It may be worthwhile, however, for one million similarly situated consumers to join their claims and pursue litigation as a class action. By doing so, they will be able to achieve sufficient economies of scale on the cost of litigation which, in turn, would transform their claim into one with PEV. When individual lawsuits have a NEV, a class action waiver will effectively block litigation against the firm and function as a de facto liability waiver. Although it is not our primary focus,

15. Many scholars have explored the choice between private and public enforcement of law. See Gary S. Becker \& George J. Stigler, Law Enforcement, Malfeasance, and the Compensation of Enforcers, 3 J. LEGAL STUD. 1 (1974); William M. Landes \& Richard A. Posner, The Private Enforcement of Law, 4 J. LEGAL STUd. 1 (1975); A. Mitchell Polinsky, Private Versus Public Enforcement of Fines, 9 J. LEGAL STUD. 105 (1980).

16. See Daniel A. Crane, The Institutional Structure of Antitrust ENFORCEMENT (2011), for a discussion of public and private antitrust enforcement.

17. The Supreme Court extolled the class-action mechanism in Deposit Guaranty National Bank v. Roper, 445 U.S. 326, 339 (1980) ("[A]ggrieved persons may be without any effective redress unless they may employ the class action device.").

18. Justice Breyer, in his dissent in Concepcion, writes, "What rational lawyer would have signed on to represent the Concepcions in litigation for the possibility of fees stemming from a \$30.22 claim?" Concepcion, 563 U.S. at 1762 (Breyer, J., dissenting). The Concepcions were charged $\$ 30.22$ in sales tax on two phones. Id. at 1761-62. 
we will also discuss settings where individual lawsuits have PEV and class actions allow plaintiffs to realize economies of scale. ${ }^{19}$

Many of the ideas in this Essay will be illustrated through the lens of products liability ${ }^{20}$ In particular, we will explore contractual clauses that prevent consumers who have suffered a loss due to defective products from aggregating their claims and bringing a single action against the manufacturers of these products. ${ }^{21}$ To anchor our analysis, we begin with a very simple benchmark of a monopolist (the "firm") that sells a product that could harm consumers. ${ }^{22}$ The marginal cost of production is assumed to be $\$ 100$. The product malfunctions at a rate of $10 \%$ per unit, causing (monetized) harm to the consumer of $\$ 1,000$, so the "average" or expected harm associated with each unit of the product sold is $10 \%$ of $\$ 1,000$ or $\$ 100 .^{23}$ We assume that if the firm were to be sued by the consumers under strict products liability, the firm is guaranteed to be found liable for the harm of $\$ 1,000$, so the only question is whether the harmed consumers find it worthwhile to bring suit.

Suppose the lawsuits brought on an individual basis have NEV: an individual consumer's cost of litigating a products liability claim is greater than the potential damage award. So, without class actions, consumers themselves must bear the accident costs and forego compensation. On the other hand, class actions have a PEV due to economies of scale. For simplicity, when class actions are allowed the litigation costs (for both consumers and the firm) fall to zero. So, when class actions are allowed, consumers who have suffered harm bring a class action and are made whole through litigation. We also assume that consumers are risk neutral, sophisticated and understand the risks that the product poses, and that there are no actions that the consumers or the firm can take to reduce the probability of an accident or mitigate the degree of harm. We will relax these assumptions later.

19. For empirical evidence of economies of scale, see generally Theodore Eisenberg \& Geoffrey P. Miller, Attorneys Fees and Expenses in Class Action Settlements: 1993-2008, 7 J. EMPIRICAL LEGAL STUD. 248 (2010); and Brian T. Fitzpatrick, An Empirical Study of Class Action Settlements and Their Fee Awards, 7 J. EMPIRICAL LEGAL STUD. 811 (2010).

20. Recent estimates suggest that products liability accounted for $11.6 \%$ of U.S. corporate class actions matters and $9.4 \%$ of U.S. corporate legal defense spending in 2020. Consumer fraud accounted for $16.0 \%$ of matters and $15.6 \%$ of spending. CARLTON FIELDS, supra note 2 , at 15 .

21. The harms could include personal injury or economic damages, such as price overcharges in the Volkswagen diesel emissions litigation. See Hiroko Tabuchi \& Jack Ewing, Volkswagen to Pay \$14.7 Billion to Settle Diesel Claims in U.S., N.Y. TIMES (June 27, 2016), https://www.nytimes.com/2016/06/28/business/volkswagen-settlement-diesel-scandal.html [https://perma.cc/283W-45UJ].

22. We focus on the monopoly (and monopsony) cases to simplify the analysis. The main thesis will stay the same even if we were to assume a competitive market structure.

23. The expected value is the probability of the harm multiplied by the amount of the harm. It is the average harm that someone would suffer if repeatedly exposed to the risky product. 


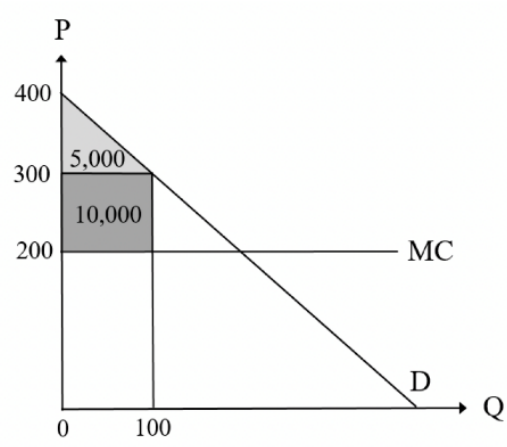

A. Class Action Allowed

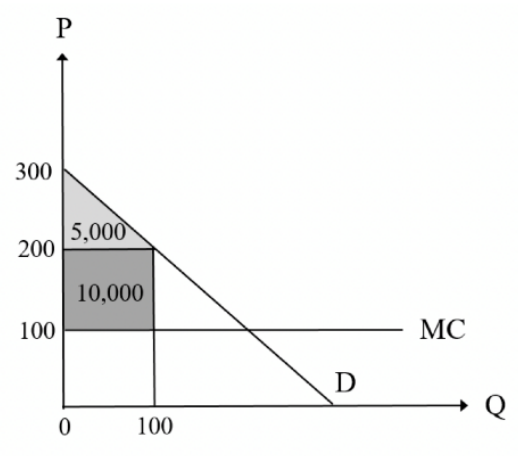

B. Class Action Blocked

Figure 1. Benchmark Example (Zero Class Action Litigation Costs, Sophisticated Consumers, No Moral Hazard)

Figure 1A shows the market outcome when the firm accepts liability and does not require consumers to sign a class action waiver as a condition of purchase. The firm's cost of selling a unit of the product is cost of manufacturing the product plus the expected future expected liability, $\$ 100+$ $\$ 100=\$ 200$. This is represented by the horizontal line labeled "MC" for marginal cost. The demand curve, labeled "D," shows the gross willingness to pay of the consumers for the product and is represented by the linear relationship of $P=\$ 400-Q$. Since the consumers (rationally) expect to be made whole after suffering accidents (through strict liability and zero litigation cost), their willingness to pay does not reflect their future harms. In Figure $1 \mathrm{~A}$, the firm charges a price $P=\$ 300$ and sells $Q=100$ units of the product.

Figure 1A shows that the sale of the product creates economic value. The shaded rectangle in Figure 1A is the producer surplus, the firm's profit margin, $P-\mathrm{MC}=\$ 300-\$ 200=\$ 100$ times the quantity sold, $Q=100$, or $\$ 10,000$. This is the net economic value that the firm gets from producing and selling the product. The shaded triangle in Figure 1A is the consumer surplus, or net economic value that consumers get from consuming the product. This is the aggregation of the very most that consumers would have been willing to pay for the product minus the price that they actually paid. The consumer surplus triangle has an area of $\$ 5,000$. The total surplus when class actions are allowed, $\$ 10,000+\$ 5,000=\$ 15,000$, is shared by the firm and the consumers. Notice that the firm captures two thirds of the total surplus and the consumers receive one third. ${ }^{24}$

24. This follows from the geometry of the example which includes a linear demand curve and constant marginal cost. 
Figure 1B shows the market outcome when the firm requires consumers to sign a class action waiver. Since class actions are blocked and individual lawsuits are prohibitively costly by assumption, this effectively "snuffs out" all future litigation and is equivalent to giving a liability waiver to the firm. Comparing Figure 1B to Figure 1A, we see that there are two differences. First, since the firm does not face future liability, their marginal cost is simply the manufacturing cost of $\$ 100$ per unit. Second, consumers are not made whole through litigation. Each consumer bears an expected loss of $\$ 100(=0.1 \times \$ 1000)$. So, each consumer's willingness to pay is $\$ 100$ lower compared to the situation in Figure 1A. For example, a consumer who would be willing to pay $\$ 400$ for the product if the losses were fully compensated is willing to pay $\$ 300$ if their losses are uncompensated. The marginal cost curve and the demand curve are both shifting down by exactly the same amount of $\$ 100$. Consequently, the price charged by the firm is $\$ 100$ lower, too: $P=\$ 200$ in Figure 1B instead of $\$ 300$ in Figure 1A.

Importantly, in our benchmark example, the decision of the firm to allow or block class actions has no effect on the either the quantity sold ( $Q$ $=100$ ), the firm's profits, or the consumer surplus. Intuitively, in a world without transactions costs, products liability reflects a simple ex-post transfer of value of $\$ 100$ from the firm to each consumer. This transfer of value is reflected in the ex-ante market price, which is $\$ 100$ higher in Figure 1A. In Figures $1 \mathrm{~A}$ and $1 \mathrm{~B}$, the producer surplus is $\$ 10,000$ and the consumer surplus is $\$ 5,000$. The overall division of value between the firm and the consumers is unchanged, too, with the firm capturing two thirds of the social surplus. Class action waivers serve no private or social purpose in our benchmark example, and so there is no need to regulate their use.

\section{Illustrative Examples}

The benchmark example above relied on several very strong assumptions: zero litigation costs, sophisticated consumers who understand the product risks, and no moral hazard on the part of the firm. ${ }^{25}$ When these assumptions are relaxed, then liability can have profound effects on the both the "size of the pie" and the allocation of the surplus between the firm and consumers. This will, in turn, have an implication on whether it is in the firm's private incentive to allow or disallow class actions and whether such private incentive is aligned with social welfare.

We now explore a series of variations of the preceding benchmark example. The first set of variations explores settings where the private ex ante incentive of the firm to block class actions is aligned with the interests of

25. Our benchmark example also assumed risk-neutral consumers. In the absence of well-functioning insurance markets, products liability has the desirable property of shifting risk from risk-averse consumers towards the firm. We will discuss the implications of risk-averse consumers in Part I.D. 
society. In these examples, the value created (or destroyed) by blocking class actions is shared with consumers and suppliers. The second set of variations explores settings where the private and social interests are not aligned. In particular, by blocking class action litigation, firms may profitably divert value from consumers, employees, and suppliers, at the expense of economic efficiency and social welfare.

\section{A. Private and Social Incentives Aligned}

In the benchmark case with no transactions cost, both the firm and the consumers were indifferent about whether to allow class actions. In this Section, we relax some of the strong assumptions embedded in the benchmark case to examine circumstances in which class actions have an impact on the market outcome. We first relax the assumptions of no (or prohibitively high) litigation costs. Next, we relax the assumption that the product risks are known and examine the problem of the firm's moral hazard. We will show that the firm is no longer indifferent between blocking and allowing class actions. However, so long as consumers are sophisticated and do not misperceive product risks, the firm's decision to block or allow class action litigation will be aligned with the interests of consumers.

\section{Costly Litigation}

Figure 2 extends our benchmark example in Figure 1 to include costs of litigation. Suppose that the consumer-plaintiffs' cost bringing a class action is $\$ 100$ per consumer and the firm's cost of litigation is also $\$ 100$ (per consumer). The consumers will file a class action once they suffer harm since the net return from litigation is positive. Since loss happens $10 \%$ of the time, this corresponds to an expected litigation cost of $(0.1) \times \$ 100=$ $\$ 10$ for the consumer and for the firm, each. On the other hand, as before, with class action waivers, it is prohibitively costly for the consumers to bring an individual lawsuit: an individual lawsuit costs more than $\$ 1,000$ per consumer and has a NEV.

The market outcome when class actions are allowed is shown in Figure $2 \mathrm{~A}$. Notice that, compared to the benchmark in Figure 1A, the demand curve has shifted down by $\$ 10$ and the firm's marginal cost curve has shifted up by $\$ 10$, reflecting the expected litigation costs. The market price is $\$ 300$ in both figures, but producer surplus is $\$ 8,100$ instead of $\$ 10,000$, and the consumer surplus is $\$ 4,050$ instead of $\$ 5,000{ }^{26}$ The firm and the consumers are both better off when class actions are blocked, as shown in Figure 2B. If the firm requires consumers to sign class action waivers as a condition of sale, no lawsuits are brought and so there are no transactions costs. This saves expected costs of $\$ 10+\$ 10=\$ 20$ per unit sold, and the total surplus

26. As before, the producer surplus is two thirds of the social surplus. 
rises from $\$ 12,150$ to $\$ 15,000$. The extra surplus created when class actions are blocked, $\$ 15,000-\$ 12,150=\$ 2,850$ in this example, is shared by the firm and the consumers.

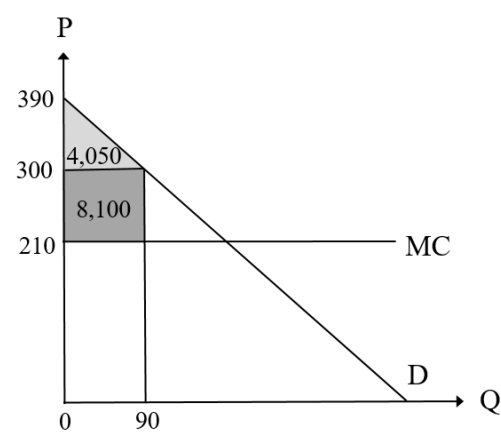

A. Class Action Allowed

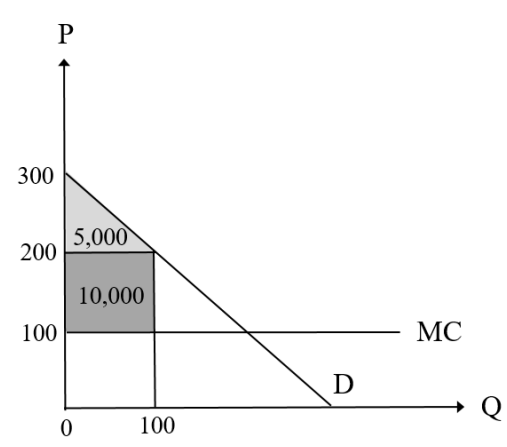

B. Class Action Blocked

Figure 2. Costly Litigation

As a general matter, if class actions are costly and have no offsetting social benefits, the firms' decision to require consumers to waive their rights to bring class actions is good for consumers, too. ${ }^{27}$ In the example above, since individual lawsuits have NEV, if class actions are blocked, consumers will not bring lawsuits and cannot recoup their accident losses ex post. Although class actions generate monetary benefits for injured consumers ex post, the consumers as a group are worse off from an ex ante perspective. If the firm allowed class actions to proceed, the firm would need to build the possibility of liability and the cost of litigation into the price of the product. When class actions are allowed, the price will rise. Since litigation is costly, involving significant transactions costs, those costs would be jointly borne by the firms and the consumers. Thus, in Figure 2, the firm's decision to block class actions by requiring consumers to sign class action waivers is socially desirable.

Conversely, if individual lawsuits have a PEV, and class actions allow economies of scale and lower the per-plaintiff litigation cost, the firm

27. Polinsky and Shavell have argued that when there is a robust market and regulatory monitoring over product safety, product liability regime becomes unnecessary. See A. Mitchell Polinsky \& Steven Shavell, The Uneasy Case for Product Liability, 123 HARV. L. REV. 1437, 144353 (2010). Baker and Choi examine how a liability regime can help when the market mechanism is imperfect. See generally Scott Baker \& Albert H. Choi, Reputation and Litigation: Why Costly Legal Sanctions Can Work Better than Reputational Sanctions, 47 J. LEGAL STUD. 45 (2018) (analyzing how reputational sanctions interact with legal sanctions). Schwartz argues that absent market failures, consumer sovereignty should be the prevailing norm. See Alan Schwartz, Proposals for Products Liability Reform: A Theoretical Synthesis, 97 YALE L.J. 353, 357-68 (1988). 
would have a private incentive to allow class actions. ${ }^{28}$ Requiring consumers to sign class action waivers would of course block class actions but would not stop litigation. Instead, a class action waiver would force the injured plaintiffs to substitute away from low-cost class actions towards higher-cost individual lawsuits. Anticipating the need to defend against costly individual lawsuits, the firm costs would rise by more than $\$ 10{ }^{29} \mathrm{In}$ addition, insofar as consumers can foresee being plaintiffs in future litigation, their demand for the product would fall by more than $\$ 10$. With individual rather than class actions, the firm's profits, consumer surplus, and social welfare would all fall in tandem. Thus, similar to the benchmark example, the firm has a private incentive to allow class actions, and allowing class actions benefits consumers and is socially desirable.

\section{Moral Hazard}

So far, we have assumed that the firm does not face any kind of moral hazard or commitment problem. If products are experience or credence goods and other enforcement mechanisms (such as market or regulatory sanctions) are not working well, firms have an economic interest in assuring consumers that the products are as represented and are safe. For example, a restaurant chain or a food processor would like to assure consumers that their food products are safe and uncontaminated and will not cause illness. Similarly, durable equipment manufacturers would like to assure consumers that their products will function properly under normal conditions. Liability is a mechanism by which firms can "bond" themselves and solve the moral hazard problems. By doing so, so long as the consumers have sufficient foresight and sophistication, the firms would increase the potential plaintiffs' willingness to pay (i.e., increase the surplus from the transaction) and also be able to realize a larger profit. Allowing class proceedings may be privately and socially optimal in these circumstances. ${ }^{30}$

28. Class action litigation may lead to higher per-plaintiff litigation costs. Although plaintiffs can avoid duplication when they consolidate their claims, plaintiffs also have a joint incentive to spend more money in the litigation contest. Specifically, combining many small lawsuits into one consolidated claim magnifies the stakes in the litigation and can stimulate more litigation spending on both sides. Firms would have a stronger incentive to block class actions in this case. See generally David Rosenberg \& Kathryn E. Spier, Incentives to Invest in Litigation and the Superiority of the Class Action, 6 J. LEGAL ANALYSIS 305 (2014).

29. Suppose that the cost of individual litigation is $\$ 800$ per unit for the firm and the consumer. Then, the demand curve would shift down by $\$ 80$ and the marginal cost curve would shift up by $\$ 80$. The price would be $\$ 300$ and the producer surplus and consumer surplus would be $\$ 400$ and $\$ 200$, respectively.

30. Not all consumer and employment contracts include class action waivers. CARLTON FIELDS, supra note 2. Recently, some firms have stopped requiring employees to submit disputes to individual arbitration. See, e.g., Daisuke Wakabayashi, Google Ends Forced Arbitration for All Employee Disputes, N.Y. TIMES (Feb. 21, 2019), https://www.nytimes.com/2019/02/21/technology/google-forced-arbitration.html [https://perma.cc/ZJF2-AY5S]. 
These ideas may be illustrated by extending our benchmark example. We now consider a moral hazard problem where product safety or reliability, along with the firm's investment to reduce accidents, is unobserved by consumers at the time of sale. As before, consumers are sophisticated and correctly perceive the incentive problems and the potential product risks: the firm's marginal manufacturing cost is $\$ 100$, and the harm caused by an accident is $\$ 1,000$. But now there is an opportunity for the firm to make the product safer or more reliable: by spending an additional $\$ 20$ per unit, ${ }^{31}$ thus raising the manufacturing cost from $\$ 100$ to $\$ 120$, the probability of harm falls from $10 \%$ to $4 \%$, reducing the average or expected harm per unit from $\$ 100$ to $\$ 40 .{ }^{32}$ Notice that this investment is socially desirable, since reduction in harm, $\$ 100-\$ 40=\$ 60$, is greater than the incremental cost of $\$ 20$.

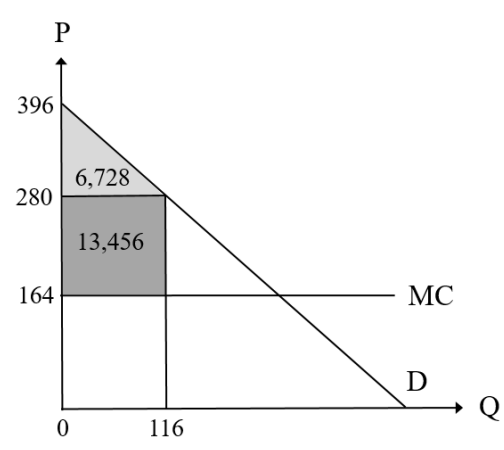

A. Class Action Allowed

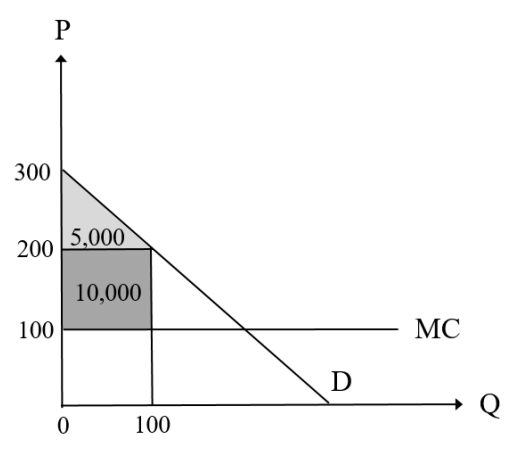

B. Class Action Blocked

Figure 3. Moral Hazard

First, suppose that the firm accepts products liability, and does not require consumers to sign class action waivers. As in the previous example, assume that the cost of class action litigation is $\$ 100$ for each consumer and the firm, whereas the cost of individual litigation is prohibitively high. Suppose the firm allows class actions and also makes the investment to reduce the probability of accident from $10 \%$ to $4 \%$. Suppose further that consumers expect the firm to make the investment, and they expect to receive compensatory damages through the class action mechanism. As shown in Figure 3A, each consumer's willingness to pay will be reduced by $\$ 4$, which is their expected cost of litigation. With the lower probability of harm, the firm's marginal cost is $\$ 100+\$ 20+(0.04)(\$ 1,000+\$ 100)=\$ 164$. The firm

31. In reality, investment in safety may be done on a lump-sum basis (e.g., through research and development). We use the per-product cost assumption to preserve the constant marginal cost and to make the analysis simple.

32. For simplicity, we assume that the firm posts its price first before the firm and the consumers make their decisions on investment and purchase. This removes the possibility of using price to signal investment. 
charges $P=\$ 280$ and earns profits of $\$ 13,456$ and consumer surplus is $\$ 6,728 .{ }^{33}$ As above, the firm captures two thirds of the social surplus and the consumers capture one third. ${ }^{34}$

Now suppose instead that the firm imposes a class action waiver on consumers and the consumers find it prohibitively costly to bring individual lawsuits against the firm. Given that the consumers do not observe the safety or reliability of the product at the time of sale, with a class action waiver, the firm has no incentive to invest the additional $\$ 20$ to reduce the probability of accidents. ${ }^{35}$ So, the firm's marginal cost of production is $\$ 100$ as shown in Figure 3B. Consumers are sophisticated and understand that products are unsafe and cause accidents $10 \%$ of the time, and that their future losses will not be compensated. This is reflected in the demand curve in Figure 3B. As in the benchmark, the firm charges $P=\$ 200$ and earns profits of $\$ 10,000$ and consumer surplus is $\$ 5,000$. Importantly, both firms and consumers are better off when class actions are allowed. The extra surplus created when class actions are allowed, $\$ 20,184-\$ 15,000=\$ 5,184$ in this example, is shared by the firm and the consumers.

The examples have shown that if class action generates significant social benefits - in particular, if it solves the problem of firm moral hazard, firms themselves may have a private incentive to allow class actions. ${ }^{36}$ If the net benefits from improvements in product safety or reliability (the reduction in the harms to consumers minus the incremental cost of producing better products) is higher than the expected costs of litigation, firm profits, consumer surplus, and social welfare are all higher when class actions are allowed. When firm profits and consumer surplus rise and fall in tandem, as illustrated in the examples above, the firm's private incentives to impose class action waivers and the social incentives are aligned.

\section{B. Private and Social Incentives Not Aligned}

There are several settings where the firms' private incentives to block class actions are socially excessive. In general, misalignments between the firms' private incentives and the social incentives may arise when the threat of class action litigation increases the size of the transactional or social surplus, but the additional value created is captured by the consumers at the

33. The firm is strictly better off making the investment. Without the investment, the firm's marginal cost rises to $\$ 100+(0.10)(\$ 1,100)=\$ 210>\$ 164$, reducing the firm's profit.

34. The total surplus is $\$ 6,728+\$ 13,456=\$ 20,184$.

35. More precisely, without any ex post liability, given that the consumers do not observe the safety or reliability of the product nor the firm's investment at the time of purchase, conditional on any price, the firm has an incentive to deviate and make no investment. In equilibrium, the firm makes no additional investment and the consumers, rationally expecting this, become willing to pay a lower price for the product.

36. The example assumes strict liability. Similar results would be obtained under the negligence standard where the firm will not be found liable if investment is made and consumers do not observe the firm's investment choice at the time of purchase. 
expense of the firms. In these circumstances, firms will attempt to block class actions and the social surplus will fall. As we will see, such problems may arise when consumers systematically misperceive the risk or the impact of waiving their rights to bring class actions. Such problems also arise when competitors get together and collude to fix prices above competitive levels. A similar misalignment arises when employers have market power and "squeeze" employees and lower the wages or other employee benefits for the purpose of maximizing profit. Still other (somewhat more subtle) misalignments occur when adverse selection is present: in a (more socially desirable) pooling equilibrium, certain consumer groups can be subsidizing others and this creates an incentive for the firms to engage in "cream-skimming" so as to grab a larger surplus from the subsidizing group.

\section{Consumer Misperceptions}

Distortions may arise when consumers misperceive the impact of signing a class action waiver or are simply unaware of the existence of the clause. Indeed, it is well documented that consumers fail to read the fine print in the contracts that they sign. ${ }^{37}$ So, as a consequence, we might not expect the inclusion or omission of a class action waiver to meaningfully change the consumers' willingness to pay for the product or the quantity demanded in the market. When consumers' willingness to pay for the product is relatively invariant to the inclusion or exclusion of a class action waiver, firms cannot capture the social benefits of class action litigation and are therefore more likely to require class action waivers as a cost-saving measure. As a consequence, firms will have inadequate incentives to make cost-justified investments to improve product safety. ${ }^{38}$

We now illustrate these ideas by extending the moral hazard example from above. Suppose that whether the firm includes a class-action waiver or not, consumers mistakenly believe that the firm will take due care when designing and producing the products and that, in the event of a harm, they will be compensated for the loss. ${ }^{39}$ Thus, the consumers' willingness to pay for the product remains unaffected by the class action waiver. Figure 4 extends the moral hazard example to reflect this new situation. Figure 4A, which is identical to Figure 3A, shows the market outcome when class actions are allowed. Following the logic outlined above, firms will make the

37. See Bakos, Marotta-Wurgler, \& Trossen, supra note 14.

38. Similar distortions arise when consumers systematically underestimate product risks. See generally Koichi Hamada, Liability Rules and Income Distribution in Product Liability, 66 AM. ECON. REV. 228 (1976); Michael Spence, Consumer Misperceptions, Product Failure and Producer Liability, 44 REV. ECON. STUD. 561 (1977).

39. In other settings, consumers might believe that they will never be compensated for their losses. In that case, the firm would have no incentive to allow class actions (remove a class action waiver), because it would expose the firm to liability without any corresponding benefits (consumer demand would not change). 
safety investment and each firm's marginal cost of production is $\$ 164$, consisting of $\$ 100$ manufacturing cost, $\$ 20$ of safety investment, and $\$ 44$ of expected cost of litigation $(0.04)(\$ 1,000+\$ 100){ }^{40}$ The firm charges $P=\$ 280$, sells 116 units and realizes $\$ 13,456$ in profits.

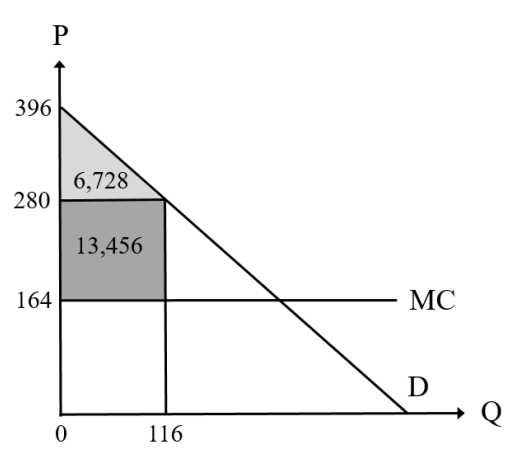

A. Class Action Allowed

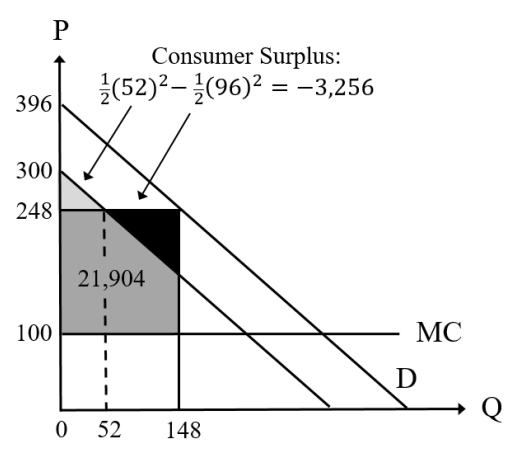

B. Class Action Blocked

Figure 4. Consumer Misperceptions

Figure 4B shows the market outcome when the firm requires consumers to sign a class action waiver and the consumers are unaware of the waiver's effects. Since consumers are unaware of the waiver, their gross willingness to pay is unchanged, so the demand curve in Figure $4 \mathrm{~B}$ (the higher downward sloping line) is exactly the same as in Figure 4A when class actions are allowed. However, the firm has no incentive to invest in product safety and so the marginal cost of production is just $\$ 100$, the manufacturing cost, just as in Figure 3B. The firm charges $P=\$ 248$, sells 148 units and realizes profits of $\$ 21,904$. Interestingly, if consumers were aware of the waiver and its implications, their gross willingness to pay for the product would be considerably less (the lower downward sloping line in Figure 4B). As a consequence, consumers in the range of $[52,148]$ along the horizontal axis are paying more for the product than it is actually worth to them! This is because consumers misperceive the risks and purchase the product even though they should not. As shown in Figure 4B, consumers, in the aggregate, are obtaining a consumer surplus of negative $\$ 3,256 .{ }^{41}$

In Figure 4, the private incentive of the firm to block class actions is socially excessive. By requiring consumers to waive their right to a class action, the firm can take advantage of consumer misperception and lower their expected marginal cost from $\$ 164$ to $\$ 100$ and raise their profits from

40. If a firm were to not make the safety investment, its expected marginal cost will, instead, be $\$ 210$, consisting of $\$ 100$ of manufacturing cost plus $\$ 110$ from litigation (0.1)( $\$ 1,000+$ $\$ 100)$.

41. Notice that the firm has no incentive to tell consumers the truth. Many products liability lawsuits allege that firms failed to disclose product risks to consumers. 
$\$ 13,924$ to $\$ 21,904$. While consumers may think that they are better off with a class action waiver, since they are paying $\$ 32$ less, the lower price is swamped by the uncompensated loss: consumer surplus falls from $\$ 6,728$ to $-\$ 3,256$. The total surplus in Figure 4B is $\$ 21,904-\$ 3,256=\$ 18,648$, which is lower than the total surplus when class actions are allowed in Figure 4A, $\$ 13,456+\$ 6,728=\$ 20,184$.

In this example, producer surplus and consumer surplus do not rise and fall in tandem. Class actions are efficient from a social perspective but reduce the firm's profits. By blocking class actions, the firm extracts value from the consumers and creates a large social loss. With consumer misperceptions, the firm's private decision to block class actions creates market distortions and causes social harm.

\section{Private Antitrust Litigation}

Firms may require consumers to waive their right to bring class actions to immunize themselves against private antitrust litigation. When public enforcement of the antitrust laws is less-than-fully effective and class actions are blocked, firms may engage in anticompetitive conduct that raises firm profits but reduces consumer surplus and social welfare. ${ }^{42}$

Let us reconsider our benchmark example where the marginal production cost is $\$ 100$. In contrast to our earlier example, we will assume that the product is perfectly safe and never causes accidents. So, products liability is not an issue. There are however antitrust concerns. Specifically, we can imagine that the product is sold not by a monopolist but by a cartel of identical firms. We will assume that public enforcement is weak and individual litigation is not viable, so if consumers sign class action waivers, firms will fix the price at the monopoly level without any risk of lawsuits. This is shown in Figure 5B, where the price that maximizes cartel profits is $\$ 250$, producer surplus is $\$ 22,500$, and consumer surplus is $\$ 11,250$. In contrast, if there is no class action waiver, then consumers may be able to bring private antitrust lawsuits against the firms for the overcharge, that is the price charged by the cartel minus the "but for" competitive price of $\$ 100$. We assume that litigation is costly, where the cost (measured per unit) of bringing an antitrust class action is $\$ 50$. As shown in Figure $5 \mathrm{~A}$, the feasibility of litigation will discipline the firms to charge $\$ 150$ instead of $\$ 250$. When the price $P=\$ 150$, consumers are (just) unwilling to pursue private antitrust litigation because the lawsuit does not have PEV. ${ }^{43}$

42. This Section is based on Albert H. Choi \& Kathryn E. Spier, Class Actions and Private Antitrust Litigation, 12 AM. ECON. J.: MICROECONOMICS (forthcoming 2021), https://ssrn.com/abstract=3329316 [https://perma.cc/94SG-7DGL].

43. This example assumes that consumers always win at trial and receive compensatory damages for the overcharge. If consumers received treble damages but won with a probability of $33 \%$ the results would be the same. 
The Economics of Class Action Waivers

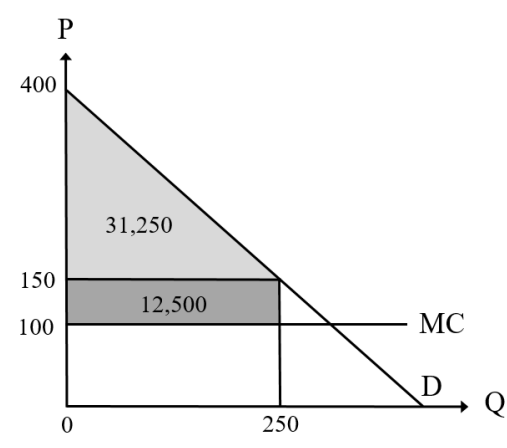

A. Class Action Allowed

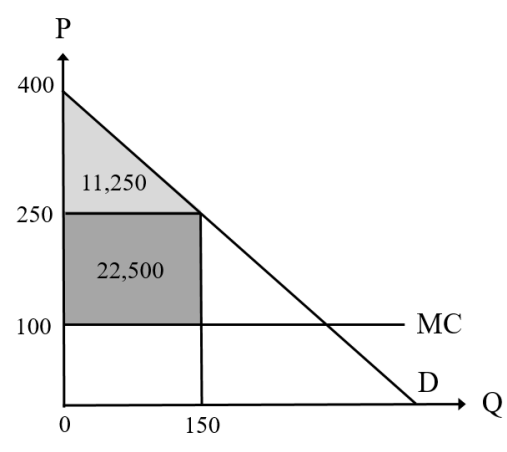

B. Class Action Blocked

Figure 5. Private Antitrust Litigation

Figures $5 \mathrm{~A}$ and $5 \mathrm{~B}$ show that allowing class actions is socially efficient. The threat of private antitrust litigation disciplines the firms to reduce their prices from $\$ 250$ to $\$ 150$, stimulating demand for the product and creating a much larger social surplus, $\$ 43,750$ versus $\$ 34,750$. But note that when class actions are allowed, the consumers capture more than two thirds of the total surplus, and the firms get less than one third. The firms have a strong incentive to block private antitrust lawsuits, since this allows the firms to charge higher prices and producer surplus rises by $\$ 22,500-$ $\$ 12,500=\$ 10,000$. Of course, this causes consumer surplus to fall by an even larger amount, $\$ 31,250-\$ 11,250=\$ 20,000$. Requiring consumers to sign class action waivers as a condition of sale allows the firms to capture a much larger share of a smaller pie.

In the products liability setting (and without consumer misperception), as the firms made a safety investment, it increased the consumers' willingness to pay and social welfare, and the firms were able to capture a significant amount of the increase in social welfare by charging a higher price. In this antitrust setting, by contrast, social welfare would increase when the firms charge a price that is close to their marginal cost. By doing so, however, all of that increase goes to the consumers and this undermines the firms' incentive to choose the optimal deterrence regime.

\section{Monopsonist Employer}

The flipside of firms' attempting to extract monopoly rent through price fixing is when a firm has too much market power as the purchaser of inputs. Imagine an employer that enjoys monopsony power in the labor market. As in the products liability setting, in this setting, we can represent the market in a graph with wages on the vertical axis and the employment level on the horizontal axis. In Figure 6, the labor demand curve is given as the downward sloping line that depicts the inverse relationship between 
the wage and the quantity while the upward sloping line shows the labor supply curve. We use the concept of "wage" as somewhat loosely to include not just the monetary compensation, but also other employee benefits, such as fringe benefits, non-hostile and non-discriminatory work environment, workplace safety, etc.

Suppose labor regulations mandate that the monopsonist employer must pay pecuniary and non-pecuniary benefits such that the workers' total monetized compensation is $\$ 15$ per hour. ${ }^{44}$ We assume that, notwithstanding the mandate, public enforcement mechanisms are insufficient, but the employees may bring private lawsuits against the employer for violations. In Figure 6A, if the employees are able to bring costless class actions against the monopsonist employer, the monopsonist will pay $\$ 15$ an hour and the equilibrium maximizes social welfare. The employer will realize the surplus of $\$ 112.5$ (represented by the light gray triangle at top) while the employees, as a group, also realize the surplus of $\$ 112.5$. If the employer attempts to reduce the compensation to a level below $\$ 15$, the employees will be able to bring a class action against the employer and force the employer to either compensate the employees or, through injunction, pay $\$ 15$ per hour.

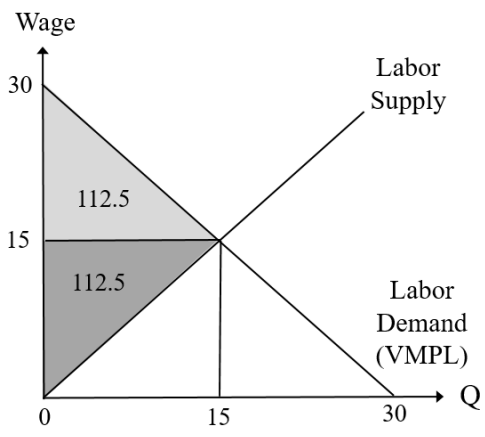

A. Class Action Allowed

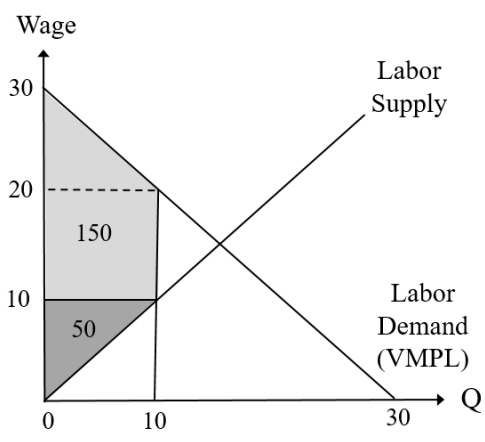

B. Class Action Blocked

\section{Figure 6. Monopsonist Employer}

But, of course, this is not the ideal outcome for the monopsonist. By conditioning employment on the signing of a class action waiver, the monopsonist can reduce the total compensation for the employees and capture a larger surplus. With the assumption, as in the benchmark case, that individual litigation is prohibitively costly, employees will no longer be able to receive compensation through litigation. This is depicted in Figure $6 \mathrm{~B}$. With a class action waiver, the monopsonist can reduce the total hourly

44. This is the "socially optimal" wage (it maximizes the sum of worker and firm surplus). In practice, regulators may not have the information necessary to do this. 
compensation down to say $\$ 10$ and realize a profit of $\$ 150$, instead of $\$ 112.5$. The employees' surplus decreases to $\$ 50$ while this exercise of monopsony power also creates a deadweight loss (since at $\$ 10$, the marginal product of labor is $\$ 20$ ). If the monopsonist is given a choice, it will choose the latter regime with no class actions, and this is socially inefficient.

The reason why the monopsonist's incentive is not aligned with maximizing social welfare is the flipside of our earlier price-fixing example. Suppose we are in regime 6B, with the equilibrium compensation of $\$ 10$ per hour. If the monopsonist were to marginally increase the compensation, say, to $\$ 11$, while the total social surplus increases (the deadweight loss shrinks), all of that increase would be captured by the employees and not the monopsonist-employer. Unless the monopsonist can engage in perfect wage discrimination, with a single wage, there is no way for the monopsonist to capture the increase in social welfare. The monopsonist's incentive of choosing the optimal litigation regime is misaligned with the social objective. ${ }^{45}$

\section{Further Considerations}

The benchmark case in Part I and the illustrative examples in Part II have relied on a variety of simplifying assumptions. Once we take into account more realistic issues, such as adverse selection and agency problems within class actions, the analysis becomes more complex, but the main theme of identifying circumstances in which the private and the social incentives diverge or converge will remain more or less the same. Rather than trying to present additional analytical examples, in this section we discuss these complexities more informally.

\section{A. Consumer Risk Aversion}

Our core insights continue to hold if consumers are risk averse. In the examples above, the consumer was assumed to be risk neutral: the monetized disutility associated with a $10 \%$ chance of accident that would cause harm of $\$ 1,000$ was exactly $\$ 100$. In reality, people are typically risk averse in the sense that a person would pay more than $\$ 100$ to avoid a $10 \%$ chance of a $\$ 1,000$ loss. Indeed, risk aversion is probably the most important reason why people buy insurance policies and seek to diversify their retirement portfolios.

If consumers are risk averse-and do not have access to competitive insurance markets - then strict liability may be an efficient mechanism for shifting risk away from the risk averse consumers towards firms who are in

45. CARLTON FIELDS, supra note 2, at 23 ("[S]ixty-seven percent of companies report that they faced at least one labor and employment class action within the last five years."). Issues include wage and hour disputes, contractor misclassifications, and data privacy. 
a better position to diversify that risk. When strict liability is socially efficient, then absent the conflating factors of consumer misperceptions discussed above, it is in the mutual interest of firms and consumers to mitigate the risk borne by consumers. Let us reconsider the benchmark example in Figure 1. If class actions are allowed, then consumers are fully insured against future losses and the outcome is exactly as in Figure 1A. The total surplus of $\$ 15,000$ is divided between the firm and the consumers with the firm receiving two thirds. If class actions are blocked and individual litigation is not viable, then the risk averse consumers suffer an expected loss of more than $\$ 100$. When class actions are blocked, consumers are exposed to risk and so the demand curve in Figure 1B would be lower than before; the firm would lower its price, sell fewer units, and firm profits and consumer surplus would fall.

\section{B. Agency Problems, Cy Pres Relief, and Frivolous Litigation}

When class actions are plagued by the problems of agency or open the floodgates for potentially frivolous litigation, ${ }^{46}$ firms would be more inclined to impose a class action waiver. Class actions are de facto controlled by lawyers who may pursue their individual objectives rather than the wellbeing of the class members. Especially when the class size is large and there is no plaintiff with a sizable claim, class members may have little or no incentive to engage in costly monitoring of the lawyer representing the class, and judicial oversight is arguably insufficient. Class action lawyers can capture the value that would otherwise go to the consumers ex post. Moreover, when the per-plaintiff recoveries are small it is common for the litigation funds to remain unclaimed and, in many cases, the funds are distributed to charities and non-profit organizations (so called "cy pres" relief). ${ }^{47}$ Then, class actions operate as an ad valorem tax on the product. Firms must raise the price to cover the expected payments to lawyers and third parties, and this reduces producer and consumer surplus. Insofar as class actions create a "sink" where value is captured by lawyers and third parties ex post, blocking class actions benefits consumers and producers (although lawyers and third parties may suffer the loss of rents).

Class action waivers may or may not be socially desirable in this setting. While the rents captured by lawyers and third parties may be viewed as a simple transfer of value, there is an important social cost from rent seeking. As the rents get larger, the price of the product rises, the quantity

46. Frivolous litigants may include parties who suffered no harm and bring lawsuits for their settlement value.

47. See generally Martin H. Redish et al., Cy Pres Relief and the Pathologies of the Modern Class Action: A Normative and Empirical Analysis, 62 FLA. L. REV. 617 (2010). BRIAN T. FITZPATRICK, THE CONSERVATIVE CASE FOR CLASS ACTIONS (2019) argues that frivolous class actions are rare and that 80 to $85 \%$ of monies paid in class action settlements go to class members. 
sold falls, and the deadweight loss grows. ${ }^{48}$ On the other hand, rent seeking by lawyers and third parties could have positive deterrence benefits, as firms take greater precautions to avoid future litigation. In this setting, the firms' private incentive to block class actions through class action waivers may be socially excessive. The firm and the consumers do not internalize the benefits to third parties from class action litigation, and therefore might tolerate more product defects than are socially desirable.

\section{Adverse Selection}

In the numerical examples, we have assumed that each consumer's propensity of suffering harm was the same. Once we relax this assumption and impose a more realistic possibility that there could be some heterogeneity among consumers regarding their propensity of suffering harm - for example, by allowing for a possible adverse selection-aligning social and private incentives with respect to class actions becomes generally more difficult. We briefly mention two possibilities here.

The first possibility is potential "cream-skimming" through a suboptimal liability provision. Suppose that consumers are heterogeneous and have private information about the likelihood that they will suffer accidents, and that when competitive firms take precautions, the likelihood of accident falls for both consumer types. There is a moral-hazard problem in that the firm's precautions are not observed at the time of sale. Class actions are socially efficient, because they give the firms the incentive to take the cost-justified precautions. However, some firms have an incentive to disallow class actions and charge a lower price. They do this in order to select (cream-skim) the low risk consumers. So, the private incentive to block class actions may be socially excessive. ${ }^{49}$

Another possibility is when a monopolist attempts to price-discriminate among different types of consumers. Suppose that consumers are heterogeneous, where the willingness to pay for a product is positively correlated with the likelihood of an accident (as may be the case with intensity of use). Note that liability is a mechanism for the consumers to get ex post "rebates" on their purchases, and the high-value consumer types get higher average rebates since they have accidents more frequently. So, if the firm

48. This is true even if lawyers and third parties are part of the social welfare calculation. Suppose in Figure 1A that the lawyer and third parties capture the benefits of litigation rather than the consumers themselves - the accident losses are uncompensated. The demand curve in Figure 1A will shift down by $\$ 100$ and cross the vertical axis at $\$ 300$. With a marginal cost of $\$ 200$, the firm will charge a price of $P=\$ 250$ and sell just 50 units of the good. Firm profits are $\$ 2,500$, consumer surplus is half this amount or $\$ 1,250$, and the lawyer/third party surplus is $\$ 5,000$. The total surplus is $\$ 8,750$, significantly less than the $\$ 15,000$ total surplus in Figure 1A.

49. This adverse selection problem was highlighted in our earlier work. See Albert H. Choi \& Kathryn E. Spier, Should Consumers Be Permitted to Waive Products Liability? Product Safety, Private Contracts, and Adverse Selection, 30 J.L. ECON. \& ORG. 734 (2014); see also Jennifer Arlen, Contracting over Liability: Medical Malpractice and the Cost of Choice, 158 U. PA. L. REV. 957 (2010). 
allows class actions, the firm is giving higher rebates to consumers who were all-else-equal willing to pay more for the product. So, liability is subsidizing the wrong consumers. Therefore, the firm will block class actions because by blocking lawsuits the firm can better price discriminate. Blocking class actions in this context is socially inefficient. When the firm blocks class actions, it chooses the product safety level that is optimal for the marginal consumer. The marginal consumer is someone who suffers accidents relatively infrequently. Therefore, product safety is insufficient. ${ }^{50}$

\section{Conclusion}

Building on the existing law and economics literature with a series of illustrative examples, this Essay has analyzed conditions under which private firms' incentive to impose class action waivers may or may not be aligned with maximizing social welfare. The issue of whether class action waiver provisions should be enforced has come to the fore through a series of recent U.S. Supreme Court cases and this Essay has attempted to provide a more nuanced, policy-based understanding of that question. While the focus has been private versus social incentive to allow class actions, this certainly isn't the only salient issue involving class action mechanisms. In this Conclusion, we highlight a few additional avenues for future research.

The first unresolved question involves unforeseen contingencies. The analytical frameworks described in this paper were premised on the litigation risks being foreseen by the market. When requiring consumers or employees to sign class action waivers, the firms fully understood the implications of their choices, and could weigh the pros and cons of the contractual options. The COVID-19 pandemic, which was unforeseen by the market, creates new challenges for both the practice and theory of law. In the first half of 2020 alone, about 500 COVID-19 related class actions were filed in a variety of industries and many companies are reporting increases in litigation activity. ${ }^{51}$ For example, so-called "business interruption" cases have been brought against insurance companies that deny coverage for businesses that had to close due to various restrictions, "refund class actions" have been brought by students against universities for not delivering the contracted services, ${ }^{53}$ and workers have brought actions with grievances

50. See generally Xinyu Hua \& Kathryn E. Spier, Product Safety, Contracts, and Liability, 51 RAND J. ECON. 233 (2020). Blocking class actions also exacerbates the moral hazard problem, further compromising product safety.

51. $70 \%$ of companies surveyed expected an increase in class action litigation and virtually none expected a decline. CARLTON FIELDS, supra note 2, at 7.

52. See, e.g., Troy Stacy Enters. v. Cincinnati Ins. Co., No. 1:20-cv-00312 (S.D. Ohio filed Apr. 19, 2020); Milkboy Ctr. City LLC v. Cincinnati Ins. Co., No. 2:20-cv-02036 (E.D. Pa. filed Apr. 27, 2020).

53. Some students allege that the quality of online education falls far short of what they could get on campus. See, e.g., Pfingsten v. Carnegie Mellon Univ., No. 2:20-cv-00716 (W.D. Pa. filed May 15, 2020). In another refund class action filing, baseball fans have attempted to bring a class action against StubHub and Ticketmaster seeking refunds for Major League Baseball tickets. 
over how their employers handled the crisis. ${ }^{54}$ In contrast to cases where future contingencies are reasonably foreseen, when class action waivers are forbidding potential plaintiffs from bringing class actions based on unforeseen contingencies, this throws a new complexity over the question of enforceability.

Another issue that needs more in-depth examination is that of class certification: determining the boundaries of the class. Our framework has assumed that whether a certain plaintiff has suffered injury and whether the plaintiff belongs in the class can be determined relatively easily. In practice, however, the problem of determining the boundaries of the class and class certification may be far from straightforward. Resolving this issue can be quite challenging, for instance, in the case of securities class actions. When class action plaintiffs allege that they suffered a loss by a company's misrepresentation, since the U.S. Supreme Court case of Halliburton, ${ }^{55}$ the defendant-company can rebut the class certification by showing that the securities market wasn't sufficiently informationally efficient and the alleged misrepresentation did not cause mispricing of the security. Similar issues can arise in product liability settings when a defendant firm tries to show that the harm suffered by the plaintiff was caused by some other factor. Drawing the right boundaries will have a significant effect on forestalling frivolous claims and overall deterrence against firms. The issues of unforeseen contingencies and class certification, just to highlight a few, raise many interesting questions that remain on the law and economics research agenda.

See Ajzenman v. Office of the Comm'r of Baseball, No. 2:20-cv-03643 (C.D. Cal. filed April 20, 2020).

54. Employees of Celebrity Cruise Lines have brought suit alleging that they were forced to remain onboard the vessel without pay when the industry was shut down. See Maglana v. Celebrity Cruises Inc., No. 1:20-cv-22133 (S.D. Fla. filed May 21, 2020).

55. Halliburton Co. v. Erica P. John Fund, Inc., 573 U.S. 258 (2014). Recently, Judge Hellerstein of the Southern District of New York rejected the settlement proposal between Harvey Weinstein and dozens of women who have accused him of sexual harassment and abuse. In the process, the judge expressed skepticism as to whether the claims should belong in the same class and whether the plaintiffs should pursue individual actions. See Jodi Kantor \& Megan Twohey, Judge, Expressing Skepticism, Upends \$25 Million Harvey Weinstein Settlement, N.Y. TIMES (July 14, 2020), https://www.nytimes.com/2020/07/14/us/harvey-weinstein-settlement.html [https://perma.cc/LN4V-5YMX]. 